\section{DIGITAL COMMONS \\ @ UNIVERSITY OF SOUTH FLORIDA}

\section{ABO: Interactive Journal for Women in the Arts, 1640-1830}

Volume 7

Issue 1 Volume 7.1 (Spring 2017)

Article 1

2017

\title{
General Editor's Note
}

Laura Runge

University of South Florida

Follow this and additional works at: https://digitalcommons.usf.edu/abo

Part of the Dramatic Literature, Criticism and Theory Commons, Educational Methods Commons, Feminist, Gender, and Sexuality Studies Commons, and the Literature in English, British Isles Commons

\section{Recommended Citation}

Runge, Laura (2017) "General Editor's Note," ABO: Interactive Journal for Women in the Arts, 1640-1830: Vol.7: Iss.1, Article 1. http://doi.org/10.5038/2157-7129.7.1.1159

Available at: https://digitalcommons.usf.edu/abo/vol7/iss1/1

This Notes from the Editor is brought to you for free and open access by Digital Commons @ University of South Florida. It has been accepted for inclusion in ABO: Interactive Journal for Women in the Arts, 1640-1830 by an authorized administrator of Digital Commons @ University of South Florida. For more information, please contact digitalcommons@usf.edu. 


\section{General Editor's Note}

\section{Creative Commons License}

(c) $($ ) $\odot$

This work is licensed under a Creative Commons Attribution-No Derivative Works 3.0 License. 


\section{General Editor's Note}

Welcome to the seventh volume of $A B O$. At the six-year mark, our journal witnessed a number of transitions in editorial leadership, and so now is an appropriate time to take stock. We are proud of the work our founding editors have accomplished in establishing this journal. As the general editor, I want to thank Jennifer Golightly, Anne Greenfield, Kirsten T. Saxton, and Nicole Spottke who each contributed to the spirit and vision that launched this innovative, collaborative experiment. We are all richer for the insights and experiences you shared with us.

Our articles have focused on the mission of the journal, which is to examine and analyze the role of women artists and gender issues in the long eighteenth century. Over the years 2011-2016 ABO published 99 articles in five categories: scholarship, pedagogy, digital humanities, reviews, and notes and discoveries. We continue to accept articles that examine such issues in their broadest terms, including an upcoming special issue on "Eighteenth-Century Camp" co-edited by Ula Lukszo Klein and Emily M.N. Kugler. In keeping with the academic mission, our half-blind peer review process has combined supportive mentoring with rigorous work, a central tenet of the Aphra Behn Society. In practice, the review process has created a collaborative relationship between writer, reviewer, and editor and has resulted in our high-quality scholarship. That we are an open-access journal has had incredible results and an international reach beyond our expectations. For instance, our most popular article continues to be "The Only Beguiled Person: Accessing Fantomina in the Feminist Classroom," by Kate Levin, with 2,385 downloads to date, distributed across the world. Our readership is quite international, with most downloads from the United States and the United Kingdom. These are followed in succession by China, Canada, India, Germany, France, the Philippines and 124 other countries. Our scholars' work has been picked up by ancestors of Melesina Trench, and we have reviewed the latest publications and digital sites relating to women and gender in the eighteenth century. We are a leading forum for the practical aspects of teaching the eighteenth century in the university classroom. We engage, in very concrete ways, with the public humanities.

We now welcome the energy and vision of four new editors. Cynthia Richards took over from me, as Pedagogy Editor, and she is shepherding her first set of pedagogy essays to press this month. In November, Tonya-Marie Howe joined us as the new Digital Humanities editor replacing Anne Greenfield. Cassie Childs is stepping into the shoes of Jennifer Golightly as the new co-managing editor. Mona Narain will begin as scholarship editor in August 2017, taking over 
from Kirsten T. Saxton. Finally, our long-time copy editor Nicole Spottke will be replaced by Jessica Cook. The mission of the journal remains the publication of rigorous, innovative articles and essays on the women in the arts, 1640-1830, but we expect to see some new directions emerge from the collective brain trust. Look for vision statements from the section editors in the fall. Please enjoy the essays in our newest issue, and come back to visit many times!

Laura Runge

General Editor

University of South Florida 